\title{
Intensification of Agriculture at Ban Chiang: Is There Evidence from the Skeletons?
}

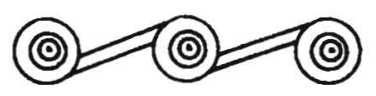

MICHAEL PIETRUSEWSKY AND MICHELE TOOMAY DOUGLAS

IN 1974 AND 1975, within The village OF BAN Chiang, northeast Thailand, two separate archaeological excavations were conducted under the direction of Chester Gorman and Pisit Charoenwongsa of the University of Pennsylvania and the Thai Fine Arts Department, respectively. The two locations (the side and backyard of a house, and a road) were chosen as unlooted areas toward the center of the village mound. Less than 0.16 percent of the approximately 8 -ha mound was excavated (White 1986:29).

These excavations and subsequent publications (e.g., Charoenwongsa 1982a, 1982 b; Douglas 1996, 1997; Goodenough 1982; Higham and Kijngam 1979, 1982; Pietrusewsky 1978, 1982, 1984, 1994, 1997; White 1982a, 1982b; Yen 1982) focused renewed attention on the prehistory of Southeast Asia. Although the original chronology proposed by Gorman and Charoenwongsa (1976) has been revised (White 1986), the evidence for early agriculture (including domesticated rice), early metallurgy (including early bronze), distinctive decorative pottery, ornaments, and elaborate burial offerings have distinguished Ban Chiang as one of the most important prehistoric settlements so far excavated in Southeast Asia. In 1992, Ban Chiang was designated a World Heritage Site.

In addition to plant and animal remains, artifacts, and evidence for habitation and metal working, the excavations at Ban Chiang resulted in the recovery of 142 inhumation burials. The skeletal remains have been the subject of ongoing research at the University of Hawai'i since their initial discovery. Because these skeletons were interred over the course of two thousand years, they represent an exceptional resource for examining both biological and cultural changes over time. A monograph (Pietrusewsky and Douglas 2002) describing the human skeletal remains from Ban Chiang has been recently published by University Museum of the University of Pennsylvania. This monograph presents a detailed discussion of some of the current issues in bioarchaeology, including the effects of sedentism and an increasing dependence on agriculture, and evidence for rank, status, and gender differences in health and disease.

Michael Pietrusewsky is a professor in the Department of Anthropology, University of Hawai'i, Honolulu. Michele Douglas received her Ph.D. in Anthropology in 1996 from the University of Hawai'i and lives in Fort Worth, Texas. 
Table i. The Archaeological Sequence at Ban Chiang

\begin{tabular}{lll}
\hline PERIOD (PHASE) & \multicolumn{1}{c}{ RESOURCE BASE } & DATES \\
\hline $\begin{array}{l}\text { Late period (IX-X) } \\
\text { Middle period (VI-VIII) }\end{array}$ & $\begin{array}{l}\text { Wet-rice agriculture. } \\
\begin{array}{c}\text { First appearance of water buffalo; loss of } \\
\text { woodland and gain of grassland. } \\
\text { Hunter-gatherer-cultivator economy. } \\
\text { Early bronze and domesticates. }\end{array}\end{array}$ & $\begin{array}{l}\text { c. } 300 \text { B.C. }- \text { A.D. } 200 \\
\text { Early period (I-V) } 900-300 \text { B.C. }\end{array}$ \\
\hline
\end{tabular}

\section{A LOST BRONZE AGE}

With the discovery of the "Lost Bronze Age" in Thailand (White 1982a) came questions about the effects of technological and environmental changes in the region (e.g., Bellwood 1997; Higham 1989, 1996; White 1995a). It is generally accepted that during the early phases of occupation of the site (see Table 1), which includes both pre-metal and Bronze-Age deposits, the inhabitants had a huntergatherer-cultivator economy that included harvesting of natural resources (e.g., game, wild fruits, fish), breeding of domesticated resources such as chickens, pigs, dogs (Higham and Kijngam 1979), and cultivation of certain plants, including rice and yams (White 1995a). Even with the introduction of bronze technology the subsistence base appears to remain remarkably consistent.

During and following the middle phases of occupation there is evidence for a change in the environment surrounding the village, with a loss of woodland and a gain in grasslands consistent with wet-rice or paddy field agriculture (Higham and Kijngam 1979). Water buffalo bones and iron implements (but none resembling plowshares) appear at this time. The water buffalo as a traction animal and iron for plow shares are common accoutrements for wet-rice agriculture, an intensified subsistence system across mainland Southeast Asia.

\section{PALAEOPATHOLOGY, SEDENTISM, AND AGRICULTURE}

The relationship between agriculture and sedentism is not absolute; agriculture may precede sedentism, and hunters and gatherers may be sedentary (Kelly 1992; Shoocongdej 1996). Sedentism may be viewed as "less mobility" (Kelly 1992:50) and may be adopted in cases of resource abundance, resource scarcity, and competition. Sedentary communities may still have degrees of mobility, for example a small group may travel to gather a certain resource, or men may go on extended hunting forays. The ramifications of sedentism include increased bacterial, viral, and parasitic infections resulting from accumulated waste and refuse, water contamination, exposure to domesticated animals, and exposure to disease vectors throughout their life cycle (Armelagos 1990; Kent 1986).

Agriculture and its intensification may result in a more restricted (perhaps less nutritionally complete) diet, improved weaning foods, and alterations in activity patterns, among other changes (Cohen 1989). Both sedentism and agriculture imply a long-term investment of time, energy, and resources that then requires defensive action, such as interpersonal conflict, resulting in an increase in violent injury. 
Studies in palaeopathology have suggested that sedentism, agriculture, and agricultural intensification, which implies refined techniques, greater time and energy expenditure, and presumably higher crop yields, results in a decline in health of populations (e.g., Cohen and Armelagos 1984; Kent 1986; Larsen 1995, 1997). These changes have been well documented in archaeological populations using a wide variety of cultigens (e.g., wheat, maize, barley, millet) in a wide variety of geographic regions, including North and South America, Europe, West Asia, Africa, and Japan (Larsen 1995, 1997; Turner 1979). The decline in health is multifactorial and likely related to the effects of both sedentism (e.g., increased population density, increased waste, water contamination, etc.) and agriculture (e.g., decline in dietary variety, quality, and quantity). The trend toward declining health, however, is not universal (e.g., Hodges 1987; Larsen 1995, 1997), and the indications of stress must be evaluated within the environmental context of each specific population, weighing such factors as the degree of intensification, agricultural products, settlement pattern, population density, contact with other groups, climate, and migratory habits.

Until recently, the effects of sedentism and agricultural intensification in South Asian (Lukacs 1992) and Southeast Asian populations have been unknown (e.g., Douglas 1996; Pietrusewsky and Douglas 2002; Tayles et al. 2000). The majority of the skeletal series from Thailand available to evaluate these questions, including the Ban Chiang series, are from groups of people that already have some of the accoutrements of sedentism, for example stilt houses, pottery, cultivated food products, and domesticated animals. It is impossible to know how sedentary the early inhabitants of Ban Chiang were (for example, they may have relocated for several months at a time), but the present archaeological evidence suggests a significant commitment to the location (White 1982a).

Cultivated rice (Oryza sativa) is the well-known staple of modern eastern Asian societies and may have been an important component of the diet in early Southeast Asian societies (Kealhofer 1996; Penny et al. 1996; Yen 1982). Rice, in both the milled and unmilled state, is a poor source of dietary protein (Larsen 1995:189) because it is an incomplete protein and must be eaten with other sources, such as meat or beans, to provide all of the essential amino acids. Rice also lacks Vitamins $\mathrm{C}$ and $\mathrm{A}$, which are necessary for normal growth and development. Thus, the intensification of rice agriculture in prehistoric Ban Chiang may have led to an over reliance on rice that may have contributed to a decline in health.

The major question examined in this paper is whether there are changes in the health, population dynamics, or physical injury of the inhabitants of Ban Chiang following the intensification of rice agriculture suggested by the archaeological record.

THE BAN CHIANG SKELETAL SERIES

The excavations at Ban Chiang were conducted within specifically circumscribed areal units and only exposed portions of the skeletal remains were removed for examination. This practice resulted in many incomplete skeletons. Prehistoric and historic disturbances of the burials were numerous, including subsequent interments; trench, hearth, and trash pit features; postholes; and animal and insect burrows. Though skeletal completeness varies by individual burial, the majority of 
the skeletons (69.0 percent, 98 of 142) include both skull and infracranial elements. More than half of the skulls (60.2 percent, 65 of 108), and infracranial skeletons (54.5 percent, 73 of 134) are partially complete or fragmentary. Most of the skeletal remains have good to fair preservation, but many of the skeletal elements required reconstruction, and all of the crania were reconstructed.

Primary, supine, extended, inhumation burial was the dominant mortuary behavior at Ban Chiang throughout the temporal sequence (White 1986). Two kinds of variable mortuary behavior were present in the sequence; 5 tightly flexed burials were recovered, and 8 of the 17 subadults under five years of age were interred within pottery jars (during the Early period). The Ban Chiang skeletal series does not represent a formal, discrete cemetery, but rather derives from the interdigitation of habitation and mortuary deposits. Still, the age and sex distributions of the entire skeletal series $(n=142)$ are consistent with the composition of a more formal cemetery.

The Ban Chiang excavations document the appearance of metal technology using copper and bronze during the Early period, and the introduction of iron in the Middle period during the first millennium B.C. (White 1986). The skeletal remains of water buffalo appear at the same time. Thus, the archaeological evidence suggests that intensified agriculture, using inundated rice fields and employing water buffalo-drawn plows, was introduced after the Early period and during the Middle period.

To examine the effects of these technological changes on the prehistoric inhabitants of Ban Chiang, the skeletal series will be divided into two subsamples, Early Group and Late Group. The Early Group includes burials from Early period I-V $(n=93)$, and the Late Group $(n=46)$ includes burials from the Middle period VI to Late period X (Table 2). Although the sample sizes are uneven, the age and sex distributions of these subsamples are consistent with a cemetery assemblage.

\section{METHODS}

The data used in this study consist of selected palaeodemographic parameters, dental caries, dental enamel hypoplasias, cribra orbitalia, adult stature, infectious lesions, and trauma. Palaeodemographic reconstructions and observations of dental and skeletal palaeopathology, including "indicators of stress," follow earlier work (Douglas 1996; Pietrusewsky and Douglas 1994; Pietrusewsky et al. 1997). Additional comments on these methods are included in the appropriate sections discussing these results. The chi-square and Fisher's exact test statistics were used to test for significant differences (Thomas 1986).

\section{RESULTS}

\section{Palaeodemography}

The relationship of demography to sedentism or agriculture is complex, incorporating both positive and negative effects. Less mobility may result in an increase in fertility and improved weaning foods, as well as an increase in infant mortality resulting from more infectious diseases in densely inhabited villages (e.g., Bentley et al. 1993; Buikstra et al. 1986; Larsen 1995:197). The demographic effects of changing subsistence are also highly specific to the population under study. 
Table 2. Age and Sex Distribution of Ban Chiang Skeletons by Temporal Periods

\begin{tabular}{|c|c|c|c|c|c|c|c|c|}
\hline \multirow[b]{2}{*}{ AGE INTERVAL } & \multicolumn{4}{|c|}{ EARLY GROUP } & \multicolumn{4}{|c|}{ LATE GROUP } \\
\hline & M & $\mathrm{F}$ & $?$ & $\mathrm{~T}$ & M & $\mathrm{F}$ & ? & $\mathrm{T}$ \\
\hline Fetal & 1 & 2 & & 3 & & & & \\
\hline NB- 0.9 & 1 & 2 & 3 & 6 & 2 & & 1 & 3 \\
\hline $1-2.9$ & 1 & 1 & & 2 & 1 & 2 & & 3 \\
\hline $3-4.9$ & 2 & 2 & 4 & 8 & & 2 & & 2 \\
\hline $5-7.9$ & 2 & 1 & 1 & 4 & 1 & 1 & 1 & 3 \\
\hline $8-9.9$ & & & 1 & 1 & & & & \\
\hline $10-14.9$ & 2 & & & 2 & & & & \\
\hline $15-19.9$ & 1 & 1 & 2 & 4 & 2 & 1 & & 3 \\
\hline $20-24.9$ & & 2 & & 2 & & 2 & & 2 \\
\hline $25-29.9$ & 3 & 4 & & 7 & & 1 & & 1 \\
\hline $30-34.9$ & 1 & & & 1 & 1 & 1 & & 2 \\
\hline $35-39.9$ & 5 & 4 & & 9 & 3 & 2 & & 5 \\
\hline $40-44.9$ & 4 & 2 & & 6 & 1 & & & 1 \\
\hline $45-49.9$ & 9 & 4 & & 13 & 1 & & & 1 \\
\hline $50+$ & 1 & 2 & & 3 & 1 & & & 1 \\
\hline Adult & 6 & 3 & 1 & 10 & & 4 & 2 & 6 \\
\hline Young adult & & 1 & & 1 & 1 & 4 & & 5 \\
\hline Middle aged & 7 & 4 & & 11 & 5 & 3 & & 8 \\
\hline Total & 46 & 35 & 12 & 93 & 19 & 23 & 4 & 46 \\
\hline
\end{tabular}

Note: Early Group = burials from Early period I-V; Late Group = burials from Middle period VILate period X; NB = newborn; $M=$ male; $F=$ female; ? = unknown sex; $T=$ total. Burials with ambiguous temporal assignments are excluded from this table. Individuals are listed under the broad categories, Adult, Young adult, and Middle aged, when more accurate ages could not be estimated.

Although the relationship of demography to sedentism or agriculture is complex, a decline in mean age-at-death or life expectancy, increased fertility, and increases in age-specific mortality and infant mortality are among the palaeodemographic changes expected to be associated with sedentism and the intensification of agriculture (e.g., Cohen and Armelagos 1984; Cook 1984; Kent 1986; Larsen 1984, 1997; Ubelaker 1984). Both mortality-based and fertility-based palaeodemographic statistics for the Early Group and Late Group burials from Ban Chiang are compared (Table 3). These palaeodemographic statistics were generated by the construction of abridged life tables.

Mortality-Based Palaeodemographic Features - Several mortality-based palaeodemographic features of the two temporal subsamples support the presence of demographic change over time at Ban Chiang (Table 3 ). Although very young children are underrepresented in both subsamples, subadults ( $\leq 20$ years) comprise 30 percent of these samples, frequencies which are within expected cemetery proportions (Weiss 1973:49). The sex ratio reverses itself over time, with males overrepresented in the Early Group $(n=137)$ and underrepresented in the Late Group $(n=83.3)$. This difference argues for sampling error, rather than a bias resulting from errors in determining sex, or cultural implications such as female infanticide.

Life expectancy at birth for the Late Group (28.1 years) is several years lower 
Table 3. Palaeodemographic Features of the Early Group and Late Group Skeletons from Ban Chiang

\begin{tabular}{|c|c|c|c|c|c|c|c|c|c|c|c|c|c|c|c|c|}
\hline \multirow[b]{2}{*}{ SAMPLE } & \multicolumn{2}{|c|}{ SUBADULTS ${ }^{\mathrm{a}}$} & \multicolumn{2}{|c|}{ ADULTS } & \multicolumn{4}{|c|}{$\begin{array}{l}\text { SEX DISTRIBUTION AND } \\
\text { SEX RATIO }\end{array}$} & \multirow{2}{*}{$\begin{array}{l}e^{\mathrm{o}} \mathrm{AT}^{\mathrm{AT}} \\
\text { BIRTH }^{\mathrm{c}}\end{array}$} & \multirow{2}{*}{$\begin{array}{l}e^{o} \text { AT } \\
15^{c}\end{array}$} & \multirow{2}{*}{$\begin{array}{c}\text { MEAN } \\
\text { AGE AT } \\
\text { DEATH }^{d}\end{array}$} & \multirow{2}{*}{$\begin{array}{l}\mathrm{D} 20+/ \\
\mathrm{D} 5+^{\mathrm{e}}\end{array}$} & \multirow{2}{*}{$\underset{\text { RATIO }}{\text { JA }}$} & \multirow{2}{*}{$\mathrm{MCM}^{\mathrm{g}}$} & \multirow[b]{2}{*}{$D R^{h}$} & \multirow[b]{2}{*}{$n^{\mathrm{i}}$} \\
\hline & $n$ & $\%$ & $n$ & $\%$ & M & F & $?$ & RATIO & & & & & & & & \\
\hline Early ${ }^{j}$ & 27 & 30.0 & 63 & 70.0 & 37 & 27 & 3 & 137 & 30.4 & 24.4 & 39.3 & 0.851 & 0.111 & 0.052 & 0.52 & 90 \\
\hline Late $\mathrm{k}^{\mathrm{k}}$ & 14 & 30.4 & 32 & 69.7 & 15 & 18 & 2 & 83.3 & 28.1 & 20.8 & 35.8 & 0.842 & 0.094 & 0.055 & 0.48 & 46 \\
\hline
\end{tabular}

a Subadults $=$ individuals aged $<20$ years; adults $\geq 20$ years of age.

${ }^{\mathrm{b}} \mathrm{M}=$ Male; $\mathrm{F}=$ Female; Sex ratio = proportion of adult ( $\geq 15$ years) males to females (Males $/$ Females $\left.\times 100\right)$.

${ }^{c} e^{\circ}=$ life expectancy at birth and at 15 years of age (or nearest age to 15 in life table).

${ }^{d}$ Mean age-at-death in individuals aged $\geq 15$ years.

${ }^{c} \mathrm{D} 20+/ \mathrm{D} 5+=$ proportion of individuals who live beyond 20 years to those who survive 5 years of life.

fJA = Juvenile: Adult Ratio, the ratio of individuals aged from five to 14.9 years to those over 20 years of age.

${ }_{\mathrm{g}} \mathrm{MCM}=$ Mean Childhood Mortality: the average of childhood mortality rates $\left({ }_{5} \mathrm{q}_{5}, 5 \mathrm{q}_{10},{ }_{5} \mathrm{q}_{15}\right)$.

h $\mathrm{DR}=$ Dependency Ratio, see text.

${ }^{i} n=$ total number of individuals used to construct life table (fetal remains omitted).

${ }^{j}$ Early Group = burials from Early period I-V.

${ }^{\mathrm{k}}$ Late Group $=$ burials from Middle period VI-Late period X. 
than the life expectancy at birth in the Early Group (30.4 years). By the age of 15 years, the decline in life expectancy is slightly greater (20.8 years in the Late Group versus 24.4 years in the Early Group), reflecting higher mortality in the Late Group burials. Life expectancy at Ban Chiang, however, is dramatically greater than the hunting-gathering-fishing Jomon people of Japan where life expectancy at age 15 years was reported to be only 16 years (Kobayashi 1967:148).

The mean adult ( $>15$ years) age-at-death in the Ban Chiang temporal subsamples also declines over time ( 39.3 to 35.8 years). However, both values fall at the high end of the range in preagricultural and agricultural prehistoric Japanese males (Kobayashi 1967:147), suggesting that, even with intensification of rice agriculture, the Ban Chiang inhabitants sustained a broad resource base and relatively "healthier" lifestyle than the prehistoric Japanese.

The birth rate, calculated from the inverse of the life expectancy at birth, increases from the Early Group (32/1000) to the Late Group (36/1000) burials, a change consistent with expectations of increased fertility in intensified agricultural economies. Declines in life expectancy and mean age-at-death, and an increase in fertility, which are expected with the transition to intensified agriculture, are supported by the mortality-based statistics of the two temporal subsamples from Ban Chiang.

Fertility-Based Estimates - Palaeodemographic proportions that emphasize fertility rather than mortality statistics provide an opportunity for assessing the demographic proportions of the two temporal subsamples that mitigate the biases of adult aging methods and the underrepresentation of subadults (Buikstra and Konigsberg 1985; Buikstra et al. 1986; Howell 1982; Jackes 1992; Lovejoy 1971). The D20+/D5+ ratio (Konigsberg et al. 1989:628), or proportion of individuals who live beyond 20 years of age to those who survive the first five years of life, is inversely related to fertility. The D20+/D5+ ratio declines slightly in the Late Group burials at Ban Chiang, suggesting an increase in fertility over time $(0.851: 0.842)$.

The juvenile : adult ratio (JA), or ratio of individuals aged from 5 to 14.9 years to those over 20 years of age (Jackes $1992: 215$ ), also decreases slightly in the later phases at Ban Chiang (0.111 to 0.094). This decline means that the proportion of juveniles to adults in the Late Group is lower than in the Early Group, and reflects a decline in fertility (Jackes 1994:176), opposite the trend indicated by the D20+/D5+ statistic. The mean childhood mortality (MCM), or average of childhood mortality rates (Jackes 1992:215), increases slightly from the Early Group to the Late Group burials (0.052 and 0.055), but the absence of any individuals in the 10-15-year age interval in the Late Group significantly impacts this value. An increase in juvenile mortality suggests an increase in fertility (Jackes 1994:179).

The dependency ratio (DR) is another proportion that is useful for visualizing the composition of the skeletal sample by evaluating the contributions of the inhabitants (Howell 1982). Assuming individuals aged less than 15 and more than 50 years as dependents, in the Early Group burials the DR (30.9/59.0 or 0.52 ) reflects two workers for every dependent, suggesting a lifestyle with reduced stress factors. This lifestyle is maintained through time, since the ratio in the Late Group burials $(14.9 / 31.17,0.48)$ is nearly identical. This result is inconsistent with expectations because increased fertility should result in increased numbers of children or dependents and an increase in the dependency ratio. 


\section{Dental Palaeopathology}

The contribution of carbohydrates relative to other components of the diet typically increases with intensifying agriculture. An increase in carbohydrate consumption may result in an increase in the skeletal indicators of dental infectious disease, such as carious lesions, dental abscessing, and premortem tooth loss (Larsen 1995 : 187; Turner 1979). In addition, agricultural intensification implies a decline in the utilization of the broad range of natural resources and concentration on a restricted food source that may not be as nutritionally complete. A decline in nutritional quality and the consequences of sedentism (e.g., poor water quality, refuse and human waste accumulation, increased exposure to infectious agents) affect the growth, development, and immunocompetence of children, and may result in increased childhood illnesses and an increase in general physiological stress. Nonspecific indicators of infant and childhood stress include the prevalence of dental enamel hypoplasias and the attainment of adult stature.

Information on two dental pathological conditions, dental caries and enamel hypoplasia, are assessed. Temporal change in the frequencies of carious lesions will reveal whether or not there is evidence for an increase in carbohydrate consumption, and temporal change in the frequencies of dental enamel hypoplasias will reveal whether there is evidence for an increase in general physiological stress.

Dental Caries - As Larsen (1995, 1997) and others (Hillson 1996:283-284; Lukacs 1989:267; Turner 1979) have noted, caries are not common until the adoption of agriculture. The subsistence economy of the Ban Chiang inhabitants included rice from the beginning of the mortuary sequence (White 1986, 1995a). Rice was a portion of a varied diet that is presumed to have also relied on yam cultivation as well as wild resources gathered from the surrounding environmental mosaic (White 1995a). Since both rice and yams are starches, increased reliance on either or both of these foods would theoretically result in an increase in carious lesion frequency. The increase in carious lesions may result from an increase in starchy-sticky foodstuffs that adhere to the teeth, or a decline in tooth wear. Rapid and severe attrition of the tooth crown surface removes the fissures that can catch and hold food particles, thus reducing the formation of carious lesions. If there is a reduction in the fiber or grit in the diet, tooth wear will be reduced and there may be an increase in carious lesions.

Turner (1979:622) documented mean carious lesion frequencies ranging from 1-2 percent of teeth in hunter-gatherers, to 4.37 percent in mixed economies, and 8.56 percent in agricultural economies. Among the groups surveyed were the Jomon of Japan, a prehistoric population with a mixed economy but with a caries rate of 7.2 percent. Turner (1979:632) suggested that this relatively high rate of carious lesions may reflect the presence of other food products high in starch, such as taro or sweet potato.

A more recent analysis of carious lesion frequencies in three archaeological skeletal series from Thailand (Tayles et al. 2000) found no evidence for an increase in frequency over time despite evidence for intensification of agriculture. In fact, the data suggested a decline in carious lesion frequency over time. The authors' conclusion was that rice is not as cariogenic as other grains associated 
Table 4. Carious Lesions in Teeth from the Early and Late Group Burials

\begin{tabular}{|c|c|c|c|c|c|}
\hline \multirow[b]{2}{*}{ TEETH } & \multicolumn{2}{|c|}{$\operatorname{EARLY}(n=44)$} & \multicolumn{2}{|c|}{ LATE $(n=20)$} & \multirow[b]{2}{*}{$P$} \\
\hline & $\mathrm{A} / \mathrm{O}$ & $\%$ & $\mathrm{~A} / \mathrm{O}$ & $\%$ & \\
\hline \multicolumn{6}{|l|}{ Maxillary } \\
\hline M3 & $10 / 39$ & 25.6 & $0 / 9$ & 0.0 & $\mathrm{~F} 0.097^{*}$ \\
\hline M2 & $9 / 56$ & 16.1 & $0 / 15$ & 0.0 & F 0.188 \\
\hline M1 & $3 / 58$ & 5.2 & $1 / 15$ & 6.7 & F 0.974 \\
\hline P4 & $0 / 63$ & 0.0 & $0 / 17$ & 0.0 & \\
\hline P3 & $1 / 59$ & 1.7 & $0 / 16$ & 0.0 & F 1.000 \\
\hline $\mathrm{C}$ & $2 / 54$ & 3.7 & $1 / 14$ & 7.1 & F 0.497 \\
\hline I2 & $1 / 49$ & 2.0 & $1 / 12$ & 8.3 & F 0.357 \\
\hline I1 & $1 / 44$ & 2.3 & $0 / 10$ & 0.0 & F 1.000 \\
\hline Max. Total & $27 / 422$ & 6.4 & $3 / 109$ & 2.8 & $\chi^{2} 0.146$ \\
\hline \multicolumn{6}{|l|}{ Mandibular } \\
\hline M3 & $11 / 41$ & 26.8 & $0 / 11$ & 0.0 & $\mathrm{~F} 0.093^{*}$ \\
\hline M2 & $11 / 59$ & 18.6 & $3 / 17$ & 17.6 & F 1.000 \\
\hline M1 & $6 / 64$ & 9.4 & $3 / 15$ & 20.0 & F 0.360 \\
\hline P4 & $1 / 66$ & 1.5 & $1 / 18$ & 5.6 & F 0.385 \\
\hline P3 & $1 / 63$ & 1.6 & $0 / 17$ & 0.0 & F 1.000 \\
\hline C & $5 / 61$ & 8.2 & $1 / 18$ & 5.6 & F 1.000 \\
\hline I2 & $1 / 43$ & 2.3 & $0 / 15$ & 0.0 & F 1.000 \\
\hline I1 & $1 / 35$ & 2.9 & $0 / 12$ & 0.0 & F 1.000 \\
\hline Mand. Total & $37 / 432$ & 8.6 & $8 / 123$ & 6.5 & $\chi^{2} 0.460$ \\
\hline Molars & $50 / 317$ & 15.8 & $7 / 82$ & 8.5 & $\chi^{2} 0.095^{*}$ \\
\hline Premolars & $3 / 251$ & 1.2 & $1 / 68$ & 1.5 & F 0.968 \\
\hline Canines & $7 / 115$ & 6.1 & $2 / 32$ & 6.3 & F 0.976 \\
\hline Incisors & $4 / 171$ & 2.3 & $1 / 49$ & 2.0 & F 1.000 \\
\hline Total & $65 / 857$ & 7.6 & $12 / 232$ & 5.2 & $\chi^{2} 0.204$ \\
\hline
\end{tabular}

Note: $n=$ number of adult and adolescent ( $>10$ years) skeletons with permanent teeth examined; $\mathrm{A}=$ affected teeth; $\mathrm{O}=$ observed teeth; $P=$ probability; Early Group $=$ burials from Early period $\mathrm{I}-\mathrm{V}$; Late Group = burials from Middle period VI-Late period X. Differences were tested using Fisher's Exact Test $(F)$ two-tailed or chi-square $\left(\chi^{2}\right)$ statistic.

* indicates statistical significance $(\alpha=0.10)$.

with agriculture and that the interaction between age, sex, diet, and all of the other dental pathologies is too complex to be reduced to a single agent.

Comparisons of the frequencies of carious lesions in the Early Group and Late Group burials from Ban Chiang (Table 4) indicate that the overall frequency of carious lesions is slightly greater in the Early Group (7.6 percent) relative to the Late Group burials ( 5.2 percent). The frequencies for both groups are quite low, falling well within the "mixed-economies" range, which has been delineated using skeletal samples worldwide (Lukacs 1989:281; Turner 1979). The difference in carious lesions frequency between the two groups is not statistically significant, a finding that is tempered by the fact that the sample sizes are small in the Late Group burials. The decline in carious lesions in these teeth is the opposite of what would be expected with an increased reliance on agricultural foodstuffs but is consistent with the findings of Tayles and her associates (Tayles et al. 2000). 
Examining the frequencies of carious lesions by jaw and tooth reveals a statistically significant decrease in carious lesions of the second and third molar teeth of the Late Group burials, the opposite of what would be expected with an increased reliance on agricultural foodstuffs.

With a caveat for small sample size, one possible explanation for the decline in carious lesions in the Late Ban Chiang sample is a decline in tooth wear; however, the majority of the molars affected are second and third molars, which typically exhibit less wear than the first molars. Carious lesions of the anterior teeth, often noted to be the result of advanced dental attrition in the whole Ban Chiang series, do not exhibit any statistically significant changes over time.

A second explanation for these enigmatic results may be that, although a transition toward intensified agriculture is occurring, the subsistence system is still broadly based and has not been completely dominated by a single food product. As a corollary to this explanation, there may be a shift from sweeter starchier carbohydrate sources (e.g., yams) toward rice, a less cariogenic carbohydrate.

Dental Enamel Hypoplasia - Changes in the prevalence of dental enamel hypoplasias in the permanent teeth can suggest changes in general physiological stress in early childhood during the development of the teeth (Goodman et al. 1984:2526; Goodman and Rose 1991:281-282; Hillson 2000:249-250; Skinner and Goodman 1992). The adoption of agriculture and its intensification typically results in a less nutritionally complete diet, and sedentism results in increased exposure to pathogens, affecting growth, development, and overall health, and resulting in an increase in enamel hypoplasias (e.g., Cohen and Armelagos 1984; Kent 1986; Larsen 1995 : 193).

In the Ban Chiang series there is a statistically significant increase over time in the overall frequency of enamel hypoplasias in the permanent teeth (Table 5). Not unexpectedly, given the predilection of the anterior teeth for hypoplasias, the incisors and canines are the most commonly affected teeth in both temporal subsamples. The significant increase in hypoplasia frequency in the Late Group burials is expected with intensified agriculture and may reflect a change in the quality or quantity of the childhood diet, increased infectious disease, or other factors.

Since each tooth class records stress at slightly different ages, these frequencies can also be examined for subtle changes in the timing of the physiological stress episodes (Wright 1997:241). The mandibular central incisors show a statistically significant increase in hypoplasias over time, suggesting a younger age for childhood stress in the Late Group burials. Examination of the other tooth class frequencies shows slight increases in the occurrence of hypoplasias in the posterior teeth but the differences are not statistically significant. Thus, the affected tooth classes suggest only one slight change in the pattern of hypoplasia age-atoccurrence.

The overall increase in hypoplasia frequency is expected with an increasing dependence upon agricultural products. The fact that the pattern of age-atoccurrence does not appear to change over time suggests that the causes of this childhood stress are remaining stable but may be exacerbated by other factors; perhaps a slight decline in nutritional quality, or a slight increase in population 
Table 5. Enamel Hypoplasias in Early and Late Group Skeletons FROM BAN CHIANG

\begin{tabular}{|c|c|c|c|c|c|}
\hline \multirow[b]{2}{*}{ TEETH } & \multicolumn{2}{|c|}{$\begin{array}{l}\text { EARLY GROUP } \\
\quad(n=44)\end{array}$} & \multicolumn{2}{|c|}{$\begin{array}{l}\text { LATE GROUP } \\
\quad(n=20)\end{array}$} & \multirow[b]{2}{*}{$P$} \\
\hline & $\mathrm{A} / \mathrm{O}$ & $\%$ & $\mathrm{~A} / \mathrm{O}$ & $\%$ & \\
\hline \multicolumn{6}{|l|}{ Maxillary } \\
\hline M3 & $1 / 35$ & 2.9 & $0 / 6$ & 0.0 & F 1.000 \\
\hline M2 & $2 / 47$ & 4.3 & $2 / 10$ & 20.0 & F 0.138 \\
\hline M1 & $0 / 46$ & 0.0 & $1 / 15$ & 6.7 & F 0.208 \\
\hline $\mathrm{P} 4$ & $4 / 57$ & 7.0 & $0 / 13$ & 0.0 & F 1.000 \\
\hline P3 & $4 / 52$ & 7.7 & $3 / 13$ & 23.1 & F 0.136 \\
\hline C & $14 / 50$ & 28.0 & $2 / 10$ & 20.0 & F 0.715 \\
\hline I2 & $8 / 43$ & 18.6 & $3 / 7$ & 42.8 & F 0.169 \\
\hline I1 & $7 / 39$ & 17.9 & $0 / 6$ & 0.0 & F 0.568 \\
\hline Max. Total & $40 / 369$ & 10.8 & $10 / 76$ & 13.2 & $\chi^{2} 0.560$ \\
\hline \multicolumn{6}{|l|}{ Mandibular } \\
\hline M3 & $1 / 36$ & 2.8 & $1 / 12$ & 8.3 & F 0.441 \\
\hline M2 & $3 / 55$ & 5.5 & $1 / 15$ & 6.7 & F 0.971 \\
\hline M1 & $1 / 54$ & 1.9 & $1 / 12$ & 8.3 & F 0.332 \\
\hline P4 & $2 / 60$ & 3.3 & $1 / 14$ & 7.1 & F 0.466 \\
\hline P3 & $4 / 58$ & 6.9 & $1 / 12$ & 8.3 & F 0.967 \\
\hline $\mathrm{C}$ & $17 / 58$ & 29.3 & $6 / 13$ & 46.2 & $\chi^{2} 0.241$ \\
\hline 12 & $2 / 40$ & 5.0 & $2 / 12$ & 16.7 & $\mathrm{~F} 0.224$ \\
\hline I1 & $1 / 31$ & 3.2 & $3 / 11$ & 27.3 & F 0.049* \\
\hline Mand. Total & $31 / 392$ & 7.9 & $15 / 101$ & 14.9 & $\chi^{2} 0.032^{*}$ \\
\hline Molars & $8 / 273$ & 2.9 & $4 / 66$ & 6.1 & F 0.259 \\
\hline Premolars & $14 / 227$ & 6.2 & $5 / 52$ & 9.6 & F 0.365 \\
\hline Canines & $31 / 108$ & 28.7 & $8 / 23$ & 34.8 & $\chi^{2} 0.563$ \\
\hline Incisors & $18 / 153$ & 11.8 & $8 / 36$ & 22.2 & $\chi^{2} 0.101$ \\
\hline Total & $71 / 761$ & 9.3 & $28 / 177$ & 15.8 & $\chi^{2} 0.011^{*}$ \\
\hline
\end{tabular}

Note: $n=$ number of individuals with permanent teeth included; Early Group = burials from Early period I-V; Late Group = burials from Middle period VI-Late period X; A = affected teeth; $\mathrm{O}=$ observed teeth; $\mathrm{P}=$ probability; $\mathrm{M}=$ molar; $\mathrm{P}=$ premolar; $\mathrm{C}=$ canine; $\mathrm{I}=$ incisor; Max. = maxillary; Mand.$=$ mandibular. Differences were tested using Fisher's Exact Test $(F)$ two-tailed or chi-square $\left(\chi^{2}\right)$ statistic.

* indicates statistical significance at $(\alpha=0.10)$.

density are causing an increased prevalence of the typical childhood stressors over time.

\section{Cribra Orbitalia}

General indicators of iron deficiency anemia (i.e., porotic hyperostosis, cribra orbitalia) are expected to increase with agricultural intensification and sedentism (Kent 1992; Larsen 1995: 199; Stuart-Macadam 1992). Exceptions to this pattern (e.g., Fairgrieve and Molto 2000; Walker 1986) suggest that factors related to iron availability, iron resorption, and disease also play a crucial role in the etiology of iron deficiency anemia. In addition to intestinal parasites, malarial parasites and 
Table 6. Cribra Orbitalia in Early and late Group Individuals from Ban Chiang

\begin{tabular}{|c|c|c|c|c|c|c|c|}
\hline & \multicolumn{2}{|c|}{ EARLY GROUP } & \multicolumn{2}{|c|}{ LATE GROUP } & \multicolumn{3}{|c|}{ TOTAL } \\
\hline & $\mathrm{A} / \mathrm{O}$ & $\%$ & $\mathrm{~A} / \mathrm{O}$ & $\%$ & $\mathrm{~A} / \mathrm{O}$ & $\%$ & $P$ \\
\hline Males & $0 / 14$ & 0.0 & $2 / 4$ & 50.0 & $2 / 18$ & 11.1 & \\
\hline Females & $2 / 9$ & 22.2 & $2 / 6$ & 33.3 & $4 / 15$ & 26.7 & \\
\hline Total Adults & $2 / 23$ & 8.7 & $4 / 10$ & 40.0 & $6 / 33$ & 18.2 & F $0.05^{*}$ \\
\hline Subadults & $5 / 9$ & 55.6 & $1 / 6$ & 16.7 & $6 / 15$ & 40.0 & F 0.29 \\
\hline Total & $7 / 32$ & 21.9 & $5 / 16$ & 31.3 & $12 / 48$ & 25.0 & $\chi^{2} 0.48$ \\
\hline
\end{tabular}

Note: Early Group = burials from Early period I-V; Late Group = burials from Middle period VILate period $\mathrm{X} ; \mathrm{A}=$ number of affected individuals; $\mathrm{O}=$ number of individuals observed. Differences were tested using Fisher's Exact Test $(F)$ two-tailed or chi-square $\left(\chi^{2}\right)$ statistic.

*indicates statistical significance at $(\alpha=0.10)$.

possible genetic anemias (e.g., thalassemia) may have been present in the prehistoric populations of Thailand and these factors would have contributed to chronic anemia (Brothwell 1991; Poolsuwan 1991; Tayles 1996).

The skeletal series from Khok Phanom Di, a prehistoric coastal site in central Thailand, has osseous evidence for the presence of a genetic anemia (Tayles 1992, 1996). The evidence includes a high frequency of cribra orbitalia, enlarged nutrient foramina, abnormal cranial vault and facial bones, and appendicular skeletal changes. Cribra orbitalia was noted in 54.4 percent ( 31 of 57) of adults and 76.9 percent (10 of 13) of subadults aged 1 to 14 years (Tayles 1992:303). None of the substantial $(n=63)$ infant $(<1$ year of age) sample was affected with cribra orbitalia.

The northeastern Thailand skeletal series from Non Nok Tha and Ban Chiang do not exhibit overwhelming evidence for genetic anemia (Douglas 1996; Pietrusewsky and Douglas 2002). In the Non Nok Tha skeletal series, cribra orbitalia was observed in 11.9 percent ( 7 of 59) of the adults and in none ( 0 of 11) of the subadults (Douglas 1996:337). In this analysis, one indicator of iron deficiency anemia, cribra orbitalia, is examined for temporal change (Table 6).

The frequencies of cribra orbitalia in Ban Chiang adults and subadults fall between the frequencies of cribra orbitalia in the Non Nok Tha and Khok Phanom Di skeletal series. The results of the temporal comparison are enigmatic, likely a reflection of the effects of the significant sample size differences between these two temporal groups. There is a statistically significant increase in adults with cribra orbitalia in the Late Group burials, which is apparently attributable to an increase in the frequency of cribra orbitalia in adult males. This increase is what would be expected given the presumption of agricultural intensification during the Middle and Late periods at Ban Chiang.

However, in the Ban Chiang subadults there is a decline in cribra orbitalia frequency from the Early Group (55.6 percent) to the Late Group burials (16.7 percent). Although the temporal difference in cribra orbitalia frequency in subadults seems quite large, it is not statistically significant. When adults and subadults are combined, there is no statistically significant change in cribra orbitalia frequency over time. 
Table 7. Mean Stature Estimates in Early and Late Group Skeletons FROM BAN CHIANG

\begin{tabular}{|c|c|c|c|c|c|c|c|}
\hline & $n$ & EARLY & $\mathrm{SD}$ & $n$ & LATE & SD & t-VALUE \\
\hline \multicolumn{8}{|c|}{ Mean Stature Estimates Based on Non-Ethnic Formulae (Sjøvold 1990) } \\
\hline Male & 17 & 166.3 & 5.7 & 12 & 167.5 & 4.9 & -0.5522 \\
\hline Female & 17 & 156.0 & 5.8 & 7 & 158.3 & 5.0 & -0.9472 \\
\hline \multicolumn{8}{|c|}{ Mean Stature Estimates Based on Thai-Chinese Formulae (Sangvichien et al. 1985, n.d.) } \\
\hline Male & 17 & 165.4 & 3.6 & 12 & 166.0 & 3.7 & -0.4373 \\
\hline Female & 17 & 153.9 & 3.2 & 7 & 154.4 & 2.6 & -0.3278 \\
\hline \multicolumn{8}{|c|}{ Mean Stature Estimates Based on American-Mongoloid Formulae (Trotter 1970) } \\
\hline Male & 17 & 167.8 & 4.8 & 12 & 168.9 & 3.2 & -0.7661 \\
\hline
\end{tabular}

Note: Mean stature estimates are based on complete bones only. $n=$ number of adults ( $>18$ years); $\mathrm{SD}=$ standard deviation; Early Group $=$ Burials from Early period I-V; Late Group $=$ Burials from Middle period VI-Late period X. Stature differences were tested for significance using Student's T-test, none of the results indicate statistical significance at $\alpha=0.10$.

\section{Adult Stature}

Stature, as an indicator of generalized stress during childhood, provides an additional evaluation of health over time in the Ban Chiang temporal subsamples. Temporal changes in adult stature are frequently the result of various stressors, including nutritional deficiencies, chronic diseases, and genetic factors (HussAshmore et al. 1982; Johnson and Zimmer 1989). While not universal, stature, as well as individual bone dimensions, is reduced in the transition from huntergatherer to agriculturally based economies (Larsen 1997:16). Table 7 summarizes the mean estimated statures for Ban Chiang males and females using several different stature estimation formulae. No statistically significant differences are found between the mean statures of Early Group and Late Group burials from Ban Chiang.

The stability of mean stature from the Early to Late periods suggests little change in the environmental and subsistence systems and maintenance of physiological stability across time.

\section{Infectious Diseases}

As human populations shift from small, mobile groups of related individuals to larger, sedentary villages, pathogens typically increase (Cohen and Armelagos 1984; Larsen 1995 : 199). Although this shift is commonly associated with agriculture, it is likely that the major factor contributing to an increase in infectious disease is sedentism (Kent 1986; Larsen 1995:199). A constellation of potential diseasecausing changes occur as people become "domesticated" or sedentary, including but not limited to continuous and close contact with accumulating human waste, water contaminants, food contaminants, domesticated animals, parasites, other human beings, and an increasing exposure to people and disease from elsewhere through trading partners.

The distribution of infectious lesions over time in the Ban Chiang skeletons is shown in Table 8. Lesions in adults are noted in both males and females. Of the five subadults with evidence for infectious disease, three are newborns, one is an 
Table 8. Temporal Distribution of Ban Chiang Skeletons with Infectious lesions

\begin{tabular}{|c|c|c|c|c|c|c|c|c|c|c|}
\hline ELEMENT AFFECTED & $\begin{array}{c}\text { EP } \\
\mathrm{I}\end{array}$ & $\begin{array}{c}\mathrm{EP} \\
\mathrm{II}\end{array}$ & $\begin{array}{l}\text { EP } \\
\text { III }\end{array}$ & $\begin{array}{l}\mathrm{EP} \\
\mathrm{IV}\end{array}$ & $\begin{array}{c}\text { EP } \\
\mathrm{V}\end{array}$ & $\begin{array}{c}\text { MP } \\
\text { VI }\end{array}$ & $\begin{array}{c}\text { MP } \\
\text { VII }\end{array}$ & $\begin{array}{l}\text { MP } \\
\text { VIII }\end{array}$ & $\begin{array}{l}\text { LP } \\
\text { IX }\end{array}$ & $\begin{array}{c}\text { LP } \\
x\end{array}$ \\
\hline Skull & & & & S,S & & & & & & \\
\hline Frontal & & & & & & & & S & & \\
\hline Parietal & & & & $M^{*}$ & & & & & $\mathrm{~F}$ & \\
\hline Occipital & & & & & & & $\mathrm{s}$ & & & \\
\hline Temporal & & & & $\mathrm{F}, \mathrm{M}$ & & M & $M$ & & & \\
\hline Ribs & & & & & $M^{*}$ & & & & & \\
\hline Hand & & & & & $M^{*}$ & & & & & \\
\hline Pelvis & & & & $M^{*}$ & $\mathrm{~F}$ & & & & & \\
\hline Femur & & & & s† & & & & & & \\
\hline Tibia & & & & $\mathrm{S} \dagger$ & $M$ & & M & & & $\mathrm{F}$ \\
\hline Total Individuals & 0 & 0 & 0 & 6 & 3 & 1 & 3 & 1 & 1 & 1 \\
\hline
\end{tabular}

Note: $E P=$ Early period; $M P=$ Middle period; $L P=$ Late period; $M=$ male; $F=$ female; $\mathrm{S}=$ subadult.

$*$ and $\dagger$ denote lesions in the same individual.

infant, and one is a child. None of the lesions noted in either adults or subadults is pathognomonic for a specific infectious disease such as tuberculosis or treponematoses (Douglas 1996:298). The relatively diffuse distribution of these cases over time, and the absence of patterns in affected lesions, supports a conclusion of localized etiologies rather than epidemic or endemic disease. The conspicuous absence of infectious lesions in the earliest phases of mortuary activity (Early period I-III) suggests there may be an increase in cases over time, but the effects of differential preservation in these early skeletons may also be a factor.

\section{Trauma}

Accidental and violence-related trauma has a mixed association with sedentism, agriculture, and intensified agriculture in archaeological skeletal samples surveyed on several continents (Cohen and Armelagos 1984:590-591; Larsen 1995:198, 1997:154-159; Milner 1995). The problems of reporting trauma and differentiating accidental from violent injury are credited with this lack of a clear trend (Cohen and Armelagos 1984:591; Larsen 1997:117), though little mention is made of the possibility that the variation observed is real. The patterns of traumatic injury in the early inhabitants of Thailand are not well known, but two interpretations based on archaeological evidence have emerged. Higham (e.g., 1996:11) has argued, based on the presence of weapons in mortuary contexts, that interpersonal conflict was likely, while White $(1982 a, 1995 b)$ has proposed low levels of conflict.

The temporal distribution of traumatic injury in the Ban Chiang skeletal series (Table 9) supports its relative randomness throughout the sequence. Traumatic injury is infrequent in both the earliest (Early period I-II) and latest (Middle period VIII to Late period) phases of the Ban Chiang mortuary sequence, and appears to increase in the intervening phases (Early period III to Middle period VII). The largest number of individuals affected $(n=7)$ is in Early period 
Table 9. Temporal Distribution of Ban Chiang Adults with Skeletal Trauma

\begin{tabular}{|c|c|c|c|c|c|c|c|c|c|}
\hline ELEMENT AFFECTED & $\begin{array}{c}\text { EP } \\
\text { I }\end{array}$ & $\begin{array}{c}\text { EP } \\
\text { II }\end{array}$ & $\begin{array}{l}\text { EP } \\
\text { III }\end{array}$ & $\begin{array}{l}\text { EP } \\
\text { IV }\end{array}$ & $\begin{array}{c}\text { EP } \\
\mathrm{v}\end{array}$ & $\begin{array}{c}\mathrm{MP} \\
\mathrm{vr}\end{array}$ & $\begin{array}{c}\text { MP } \\
\text { VII }\end{array}$ & $\begin{array}{l}\text { MP } \\
\text { VIII }\end{array}$ & $\begin{array}{c}\mathrm{LP} \\
\mathrm{Ix}-\mathrm{x}\end{array}$ \\
\hline Skull & & & & $M^{*}$ & & $\mathrm{M} \dagger$ & $M^{*}$ & & \\
\hline Shoulder dislocation & & & & & & & $\mathrm{M}^{*}$ & & \\
\hline Humerus & & & & $\mathrm{F}$ & M & & & & \\
\hline Radius & & & & $\mathrm{F}, \mathrm{F}$ & & & & & \\
\hline Hand & & & $M$ & & & & $\mathrm{M}$ & & $\mathrm{M}$ \\
\hline Femur & & & & & $M$ & & & & \\
\hline Tibia & & & $M^{*}$ & & & & & & \\
\hline Contusion & & & & $M \dagger$ & & & & & $\mathrm{F}$ \\
\hline Foot & & & & & & & $M^{*}$ & & \\
\hline Vertebrae & & & & $M^{*}$ & & $\mathrm{M} \dagger$ & & & \\
\hline Spondylolysis & & $\mathrm{F}$ & & $\mathrm{M} \dagger$ & $F^{*}, F$ & & & & \\
\hline Ribs & & & $\mathrm{M}^{*}$ & $\mathrm{M}, \mathrm{F}$ & $\mathrm{F}^{*}$ & & M & & \\
\hline Individuals & 0 & 1 & 2 & 7 & 4 & 1 & 3 & 0 & 2 \\
\hline
\end{tabular}

Note: $\mathrm{EP}=$ Early period; $\mathrm{MP}=$ Middle period; $\mathrm{LP}=$ Late period; $\mathrm{M}=$ male; $\mathrm{F}=$ female.

Burials with a phase range are placed in the later phase in this chart.

$*$ and $\dagger$ denote fractures occurring in the same individual.

IV. This apparent clustering is probably a reflection of differing sample sizes since the largest number of burials were recovered from the Early period IV to Middle period VII phases.

The most common fracture is that of the ribs, found in five individuals (two females and three males), distributed over four phases. The rib fractures are typically multiple, occur in the mid to lower ribs (i.e., fifth to twelfth) and are all on the left side. Other than this, there are no patterns in these injuries: no fractures of similar size and shape, no defensive injuries, and no in situ weapons (Douglas $1996: 293,1997)$. Moreover, 8 of the 20 individuals ( 40.0 percent) with traumatic injuries are females. These observations do not negate the possibility of warfare but certainly argue against it as a prevalent behavior.

\section{DISCUSSION OF RESULTS AND CONCLUSIONS}

Reference models for populations from all over the world undergoing the shift to sedentism, agriculture, and the intensification of agriculture predict a decline in health resulting from multiple factors. These factors include a decrease in dietary quality, quantity, and variability, and an increase in parasitism and infectious disease. Examination of the Ban Chiang skeletal series for changes over time in selected indicators of health and disease yields mixed results. Despite the fact that the mortuary complex at Ban Chiang spans more than two millennia and encompasses a period of known agricultural intensification, there is little evidence for major changes in the health of these early inhabitants. Moreover, where there is evidence of temporal change, it does not always conform to the patterns predicted by the conventional model of the kinds and directions of change expected in populations undergoing agricultural intensification.

Comparisons of palaeodemographic parameters in the Early Group (presumed hunter-gatherer-cultivators) and Late Group burials (presumed intensified agri- 
culturalists) at Ban Chiang give inconsistent results. An increase in fertility over time is suggested by the birth rate $\left(1 / \mathrm{e}^{\mathrm{o}} \mathrm{b}\right)$, the D $20+/ \mathrm{D} 5+$ ratio, and mean childhood mortality, but a decrease in fertility is suggested by the juvenile: adult and dependency ratios. Indications of increased mortality in the Late Group burials at Ban Chiang are more consistent and include declines in mean age-at-death, life expectancy at birth, and life expectancy at age 15 years. However, most of these temporal differences are slight and these results must be viewed with caution given the very small sample sizes, biases of the overall skeletal sample, and problems inherent in palaeodemographic analysis.

Though the expected increase in fertility associated with intensified agriculture is not seen in the Ban Chiang skeletal series, there is an apparent trend toward increasing mortality in the Late Group burials. A larger Late period skeletal sample from Ban Chiang would help resolve some of the inconsistencies in this palaeodemographic analysis and substantiate this apparent trend toward increased mortality with intensified agriculture. Perhaps the most interesting conclusion to be drawn from this palaeodemographic analysis is that there is no evidence for dramatic changes in Ban Chiang palaeodemography over the time frame of the occupation of the site.

The evidence for a decline in health in the Ban Chiang skeletal series, evaluated by comparing frequencies of two dental pathological conditions, carious lesions and dental enamel hypoplasias, over time, is also enigmatic. An increased reliance on a cereal diet and decreased dietary variety, which typically accompanies agricultural intensification, usually results in an increase in dental caries. The opposite trend was found in the Ban Chiang remains, the prevalence of carious lesions shows a decline in the later phases. The decline in carious lesions may reflect a decrease in dental attrition that occurs with the shift from tough, fibrous, gathered foods to agricultural products. More important perhaps is that the overall frequency of carious lesions throughout the sequence is less than 10 percent, falling into the range of "pre-agricultural" or mixed economies. This finding suggests that the diet continued to be diverse and broadly based throughout the mortuary sequence (i.e., from the pre-metal through the Iron Ages) at Ban Chiang and that the diet may not have been as cariogenic a diet as occurs in other intensified agricultural systems.

Contrary to the dental caries data, the frequencies of dental enamel hypoplasias exhibit the anticipated increase over time. However, the pattern of peak age-atoccurrence of the defects remains consistent over time. The temporal sample sizes are very small and the temporal distribution of these skeletons may be too close to the transition to intensification to be registering the changes. Again, a larger skeletal sample from the Late period at the site would contribute to the resolution of this question.

In addition to the expected increase in dental enamel hypoplasias, the combined effects of sedentism, increasing population density, and agricultural intensification are expected to result in an increase in other indicators of physiological stress such as cribra orbitalia, infectious disease, and trauma, and a decline in adult stature. Cribra orbitalia frequency in adults increases over time but declines in subadults, an enigmatic result that suggests small sample biases are affecting the analysis. Alternatively, this result may suggest increased mortality in the subadults in the later phases of the mortuary sequence (a finding not supported by the palaeodemography). Contrary to expectations, no significant change in mean stat- 
ure between the temporal subsamples is found, and no temporal patterns in infectious lesions could be identified.

Societies often show evidence for increased interpersonal conflict with agricultural intensification, leading to intercommunity violence. During the Ban Chiang sequence, the occasional spear point, axe, and arrowhead were found, which might be expected to suggest interpersonal violence, but the temporal distribution of trauma shows no evidence for wounds consistent with systematic warfare as would be expected with agricultural intensification.

Factors useful in the consideration of these results are the archaeological evidence for extreme variability in mortuary ritual, site use, pottery forms, and so forth that characterizes this period in the prehistory of Thailand (e.g., White $1995 b)$. Such variability implies a variety of solutions to the consequences of sedentism and intensified agriculture. Another factor is the tropical monsoonal environment, which, though also unpredictable, allows a wide range of hunting and gathering possibilities (e.g., fishing, garden hunting, expansion of natural habitats for cultigens). Although there may have been an increased emphasis on rice over time, there was not an increased dependence on rice. The long-term effects of intensified rice agriculture may not be visible in the samples selected for this analysis; sex differences in temporal changes have not been examined completely. Further examination of these subtle temporal patterns may lead to a fuller appreciation of intriguing details in human biological history in Southeast Asia.

In conclusion, the skeletal evidence at Ban Chiang supports an overall continuity in the health status of these prehistoric inhabitants, with only a few relatively subtle changes over time. Agricultural intensification seems not to have had as dramatic an impact on the skeletal biology of this group of people in comparison to other groups, such as the Amerindians with the introduction of maize. Thus, the prehistoric inhabitants of Ban Chiang appear to be an exception to the general model of declining health over time.

\section{ACKNOWLEDGMENTS}

We wish to acknowledge the support and assistance of the late Chester Gorman of the University of Pennsylvania Museum and Pisit Charoenwongsa of the Thai Fine Arts Department, co-directors of the 1974-1975 excavations at Ban Chiang. We further acknowledge Joyce $\mathrm{C}$. White, the present director of the Ban Chiang Project at the University Museum, University of Pennsylvania, and Christine Hensley Sherman, assistant editor, for their ongoing and untiring assistance with the monograph that describes the human skeletal remains from Ban Chiang. Financial assistance for research on the human skeletal remains from Ban Chiang has been received from the Ford Foundation, National Science Foundation, University of Hawai' $i$, and the University Museum, University of Pennsylvania. An earlier version of this paper was presented in the symposium entitled, "Current Archeological Research in Southeast Asia," organized by Judy Volker, at the 65th annual meeting of the Society for American Archaeology held in Philadelphia, April 5-9, 2000.

\section{REFERENCES CITED}

Armelagos, G. J.

1990 Health and disease in prehistoric populations in transition, in Disease in Populations in Transition: 127-144, eds. A. C. Swedlund and G. J. Armelagos. New York: Bergin and Garvey. 
BeLlwoOd, P.

1997 Prehistory of the Indo-Malaysian Archipelago. Revised edition. Honolulu: University of Hawai'i Press.

Bentley, G. R., G. Jasieńska, and T. Goldberg

1993 Is the fertility of agriculturists higher than that of nonagriculturists? Current Anthropology $34: 778-785$.

Brothwell, D. R.

1991 On zoonoses and their relevance to paleopathology, in Human Paleopathology: Current Synthesis and Future Options: 18-28, eds. D. J. Ortner and A. C. Aufderheide. Washington, D.C.: Smithsonian Institution Press.

Buikstra, J. E., AND L. W. Konigsberg

1985 Paleodemography: Critiques and controversies. American Anthropologist 87:316-333.

\section{Buikstra, J. E., L. W. Konigsberg, and J. Bullington}

1986 Fertility and the development of agriculture in the prehistoric Midwest. American Antiquity 51:528-546.

\section{Charoenwongsa, Pistr}

$1982 a$ Ban Chiang in retrospect. What the expedition means to archaeologists and the Thai public. Expedition 24(4): 13-16.

$1982 b$ Introduction, in Ban Chiang: Discovery of a Lost Bronze Age: 8-11, ed. J. C. White. Philadelphia: The University Museum, University of Pennsylvania, and Washington, D.C.: The Smithsonian Institution.

Cohen, M. N.

1989 Health and the Rise of Civilization. New Haven: Yale University Press.

Cohen, M. N., and G. J. Armelagos

1984 Paleopathology at the origins of agriculture: Editors' summation, in Paleopathology at the Origins of Agriculture: 585-601, eds. M. N. Cohen and G. J. Armelagos. New York: Academic Press.

Cook, D. C.

1984 Subsistence and health in the lower Illinois valley: Osteological evidence, in Paleopathology at the Origins of Agriculture: 235-269, eds. M. N. Cohen and G. J. Armelagos. New York: Academic Press.

Douglas, M. T.

1996 Paleopathology in Human Skeletal Remains from the Pre-metal, Bronze, and Iron Ages, Northeastern Thailand. Ph.D. diss., University of Hawai'i, Honolulu. Ann Arbor: University Microfilms.

1997 A preliminary discussion of trauma in the human skeletons from Ban Chiang, northeast Thailand. Bulletin of the Indo-Pacific Prehistory Association 16:111-118.

Fairgrieve, S. I., AND J. E. Molto

2000 Cribra orbitalia in two temporally disjunct population samples from the Dakhleh Oasis, Egypt. American Journal of Physical Anthropology $111: 319-331$.

GoOdenOugh, W. H.

1982 Ban Chiang in world ethnological perspective, in Ban Chiang: Discovery of a Lost Bronze Age: 52-53, ed. J. C. White. Philadelphia: The University Museum, University of Pennsylvania, and Washington, D.C.: The Smithsonian Institution.

Goodman, A. H., D. L. Martin, and G. J. Armelagos

1984 Indications of stress from bone and teeth, in Paleopathology at the Origins of Agriculture: 1349, eds. M. N. Cohen and G. J. Armelagos. New York: Academic Press.

Goodman, A. H., AND J. C. Rose

1991 Dental enamel hypoplasias as indicators of nutritional status, in Advances in Dental Anthropology: 279-293, eds. M. A. Kelley and C. S. Larsen. New York: Wiley-Liss.

Gorman, C. F., and Pisit Charoenwongsa

1976 Ban Chiang: A mosaic of impressions from the first two years. Expedition 18(4):14-26.

Higham, C.

1989 The Archaeology of Mainland Southeast Asia: From 10,000 B.C. to the Fall of the Angkor. Cambridge: Cambridge University Press.

1996 The Bronze Age of Southeast Asia. Cambridge: Cambridge University Press. 
Higham, C., And A. Kijngam

1979 Ban Chiang and northeast Thailand: The paleoenvironment and economy. Journal of Archaeological Science 6:211-233.

1982 Prehistoric man and his environment. Evidence from Ban Chiang faunal remains. Expedition 24(4): 17-24.

Hillson, S.

1996 Dental Anthropology. Cambridge: Cambridge University Press.

2000 Dental pathology, in Biological Anthropology of the Human Skeleton: 249-266, eds. M. A. Katzenberg and S. R. Saunders. New York: Wiley-Liss.

Hodges, D. C.

1987 Health and agricultural intensification in the prehistoric valley of Oaxaca, Mexico. American Journal of Physical Anthropology $73: 323-332$.

Howell, N.

1982 Village composition implied by a paleodemographic life table. The Libben site. American Journal of Physical Anthropology 59:263-269.

Huss-Ashmore, R., A. H. Goodman, and G. J. Armelagos

1982 Nutritional inference from paleopathology, in Advances in Archaeological Method and Theory, vol. 5: 436-474, ed. M. B. Schiffer. New York: Academic Press.

JACKES, $M$.

1992 Paleodemography: Problems and techniques, in Skeletal Biology of Past Peoples: Research Methods: 189-224, eds. S. R. Saunders and M. A. Katzenberg. New York: Wiley-Liss.

1994 Birth rates and bones, in Strength in Diversity: A Reader in Physical Anthropology: 155-185, eds. A. Herring and L. Chan. Toronto: Canadian Scholars' Press.

JoHnson, F. E., AND L. O. Zimmer

1989 Assessment of growth and age in the immature skeleton, in Reconstruction of Life from the Skeleton: 11-22, eds. M. Y. İscan, and K.A.R. Kennedy. New York: Alan R. Liss.

KEALHOFER, L.

1996 The human environment during the terminal Pleistocene and Holocene in northeastern Thailand: Phytolith evidence from Lake Kumphawapi. Asian Perspectives 35(2): 227-254.

KeLLy, R. L.

1992 Mobility/sedentism: Concepts, archaeological measures, and effects. Annual Review of Anthropology $21: 43-66$.

KENT, S.

1986 The influence of sedentism and aggregation on porotic hyperostosis and anaemia: A case study. Man $21: 605-636$.

1992 Anemia through the ages: Changing perspectives and their implications, in Diet, Demography, and Disease: Changing Perspectives on Anemia: 1-30, eds. P. Stuart-Macadam and S. Kent. NewYork: AJdine de Gruyter.

Kobayashi, $\mathrm{K}$.

1967 Trend in the length of life based on human skeletons from prehistoric to modern times in Japan. Journal of the Faculty of Science, the University of Tokyo. Sec. 5: Anthropology 3(2) : 107-162.

Konigsberg, L. W., J. E. Buikstra, and J. Bullington

1989 Paleodemographic correlates of fertility: A reply to Corruccini, Brandon, and Handler and to Holland. American Antiquity $54: 626-636$.

LARSEN, C. S.

1984 Health and disease in prehistoric Georgia: The transition to agriculture, in Paleopathology at the Origins of Agriculture: 367-392, eds. M. N. Cohen and G. J. Armelagos. New York: Academic Press.

1995 Biological changes in human populations with agriculture. Annual Review of Anthropology 24: 185-213.

1997 Bioarchaeology: Interpreting Behavior from the Human Skeleton. Cambridge: Cambridge University Press.

LOvejox, C. O.

1971 Methods for the detection of census error in paleodemography. American Anthropologist 73: 101-109. 
Lukacs, J. R.

1989 Dental paleopathology: Methods for reconstructing dietary patterns, in Reconstruction of Life from the Skeleton: 261-286, eds. M. Y. İşcan and K.A.R. Kennedy. New York: Alan R. Liss.

1992 Dental paleopathology and agricultural intensification in South Asia: New evidence from Bronze Age Harappa. American Journal of Physical Anthropology 87:133-150.

Milner, G. R.

1995 An osteological perspective on prehistoric warfare, in Regional Approaches to Mortuary Analysis: 221-244, ed. L. A. Beck. New York: Plenum Press.

Penny, D., J. Grindrod, and P. Bishop

1996 Holocene palaeoenvironmental reconstruction based on microfossil analysis of a lake sediment core, Nong Han Kumphawapi, Udon Thani, Northeast Thailand. Asian Perspectives 35(2) : 209-228.

Pietrusewsky, $M$.

1978 A study of early metal age crania from Ban Chiang, Northeast Thailand. Journal of Human Evolution 7:383-392.

1982 The ancient inhabitants of Ban Chiang. The evidence from the human skeletal and dental remains. Expedition 24(4) : 42-50.

1984 Pioneers on the Khorat Plateau: The prehistoric inhabitants of Ban Chiang. Journal of the Hong Kong Archaeological Society 10:90-106.

1994 Report on new field work on Bronze-Age skeletons from Ban Chiang, Northeast Thailand, in The East Asian Tertiary/Quaternary Newsletter No. 18/1994: 81-82, ed. N. G. Jablonski.

1997 The people of Ban Chiang: An early Bronze-Age site in northeast Thailand. Bulletin of the Indo-Pacific Prehistory Association 16:119-148.

Pietrusewsky, M., and M. T. Douglas

1994 An osteological assessment of health and disease in precontact and historic (1778) Hawai ${ }^{2}$, in In the Wake of Contact: Biological Responses to Conquest: 179-196, eds. C. S. Larsen and G. R. Milner. New York: Wiley-Liss.

2002 Ban Chiang, a Prehistoric Village Site in Northeast Thailand I: The Human Skeletal Remains. Philadelphia: The University of Pennsylvania Museum of Archaeology and Anthropology.

Pietrusewsky, M., M. T. Douglas, and R. M. Ikehara-Quebral

1997 An assessment of health and disease in the prehistoric inhabitants of the Mariana Islands. American Journal of Physical Anthropology 104:315-342.

Poolsuwan, Samerchai

1991 Malaria and the Evolution of Human Beta-Globin Polymorphisms in Southeastern Asia. Ph.D. diss., University of Michigan, Ann Arbor. Ann Arbor: University Microfilms.

Sangvichien, Sanjai R., Vasan Srisurin, and Vebra Watthanayingsakul

1985 Estimation of stature of Thai and Chinese from the length of the femur, tibia and fibula. Siriraj Hospital Gazette 37:215-218.

Sangvichien, Sanjal, Vasan Srisurin, Vebra Watthanayingsakul, Pattraporn TheeraRATTAKUL, AND SUNTHRON RAKVANichPong

n.d. Equations for estimation of the Thai's stature from the length of long bones (a preliminary report). Ms., Department of Anatomy, Faculty of Medicine, Siriraj Hospital, Mahidol University, Bangkok, Thailand.

ShOOCONGDEJ, RASMi

1996 Rethinking the development of sedentary villages in western Thailand. Bulletin of the Indo-Pacific Prehistory Association 14 : 203-215.

Syøvold, T.

1990 Estimation of stature from long bones utilizing the line of organic correlation. Human Evolution 5: 431-447.

Skinner, M., and A. H. Goodman

1992 Anthropological uses of developmental defects of enamel, in Skeletal Biology of Past People: Research Methods: 153-174, eds. S. R. Saunders and M. A. Katzenberg. New York: Wiley-Liss. 
Stuart-Macadam, P.

1992 Anemia in past human populations, in Diet, Demography, and Disease: Changing Perspectives on Anemia: 151-170, eds. P. Stuart-Macadam and S. Kent. New York: Aldine de Gruyter.

TAYLES, $N$.

1992 The People of Khok Phanom Di: Health as Evidence of Adaptation in a Prehistoric Southeast Asian Population. Unpublished Ph.D. diss., Department of Anatomy, University of Otago, Dunedin, New Zealand.

1996 Anemia, genetic diseases, and malaria in prehistoric Mainland Southeast Asia. American Journal of Physical Anthropology 101:11-27.

Tayles, N., K. Dometr, and K. Nelsen

2000 Agriculture and dental caries? The case of rice in prehistoric Southeast Asia. World Archaeology $32: 68-83$.

THOMAS, D. H.

1986 Refiguring Anthropology: First Principles of Probability and Statistics. Prospect Heights, Illinois: Waveland Press.

TrotTER, $M$.

1970 Estimation of stature from intact long limb bones, in Personal Identification in Mass Disasters: 71-83, ed. T. D. Stewart. Washington, D.C.: Smithsonian Institution.

TURNER, C. G. II

1979 Dental anthropological indications of agriculture among the Jomon people of central Japan. American Journal of Physical Anthropology 51:619-636.

UBelaKer, D. H.

1984 Prehistoric human biology of Ecuador: Possible temporal trends and cultural correlations, in Paleopathology at the Origins of Agriculture: 491-513, eds. M. N. Cohen and G. J. Armelagos. New York: Academic Press.

WALKER, P. L.

1986 Porotic hyperostosis in a marine-dependent California Indian population. American Journal of Physical Anthropology 69:345-354.

WEISS, K. M.

1973 Demographic models for anthropology. American Antiquity 38(2): 1-186.

White, J. C.

1982a Ban Chiang: Discovery of a Lost Bronze Age. Philadelphia: The University Museum, University of Pennsylvania and Washington, D.C.: The Smithsonian Institution.

$1982 b$ Natural history investigations at Ban Chiang. The study of natural resources and their use today aids reconstruction of early village farming in prehistory. Expedition $24(4): 25-32$.

1986 A Revision of the Chronology of Ban Chiang and its Implications for the Prehistory of Northeast Thailand. Ph.D. diss., University of Pennsylvania, Philadelphia. Ann Arbor: University Microfilms.

1995a Modeling the development of early rice agriculture: Ethnoecological perspectives from northeast Thailand. Asian Perspectives 34(1):37-68.

$1995 \mathrm{~b}$ Incorporating heterarchy into theory on socio-political development: The case from Southeast Asia, in Heterarchy and the Analysis of Complex Societies: 101-123, eds. R. M. Ehrenreich, C. L: Crumley, and J. E. Levy. Archaeological Papers of the American Anthropological Association No. 6, American Anthropological Association, Arlington, Virginia.

WRIGHT, L. E.

1997 Intertooth patterns of hypoplasia expression: Implications for childhood health in the Classic Maya collapse. American Journal of Physical Anthropology 102:233-247.

YEN, D. E.

1982 Ban Chiang pottery and rice. Expedition 24:51-64.

\section{ABSTRACT}

Human skeletal remains excavated in 1974-1975 at Ban Chiang, a premetal to Bronze/Iron Age site located in northeastern Thailand, are used to examine the 
health effects of sedentism and agricultural intensification. The archaeological sequence provides evidence for the introduction of iron and water buffalo in the Middle period, suggesting the beginning of intensified agriculture. The effects of this agricultural intensification on the paleodemography, health, and patterns of traumatic injury of Ban Chiang's early inhabitants is examined. The skeletal and dental attributes examined include palaeodemographic parameters, dental caries, dental enamel hypoplasia, cribra orbitalia, stature, skeletal infections, and trauma. The results of this analysis are mixed. There are decreases in life expectancy and mean age-at-death that are consistent with a decline in health over time, but evidence for an increase in fertility, expected with intensified agriculture, is not found. Expected temporal increases in dental enamel hypoplasia and adult cribra orbitalia are documented. However, the expected decline in adult stature and expected increases in dental caries, cribra orbitalia in subadults, skeletal infection, and traumatic injury are not found. Overall, the skeletal indicators support continuity in Ban Chiang health, suggesting continuous reliance on a broadly based subsistence system. These findings do not fit the typical pattern demonstrated for other human groups experiencing the transition to sedentism and intensified agriculture and may support the contention that Southeast Asia's archaeological sequence differs markedly from those studied elsewhere in the world. KEYwORDs: palaeopathology, palaeodemography, dental pathology, bioarchaeology, rice, agriculture, prehistory, Thailand, Southeast Asia. 